\title{
パルス通電焼結法による形状記憶合金粒子分散材料の作製
}

\author{
浅岡 照夫，村岡 裕之 \\ 東京電機大学理工学部知能機械工学科, ₹ 350-0394 埼玉県比企郡鳩山町.
}

\section{Fabrication of SMA Particle Dispersed Materials by Pulse Electric Current Sintering}

\author{
Teruo Asaoka and Hiroyuki Muraoka \\ Dept. Intelligent Mech. Eng., Fac. Sci. Eng., Tokyo Denki University, Hatoyama, Hiki-gun, Saitama 350-0394.
}

Received April 21, 2000

\begin{abstract}
SYNOPSIS
The authors tried to fabricate the shape memory alloy (SMA) particle dispersed materials by pulse electric current sintering and to investigate the microstructures of particle-matrix interface. Ti-Ni alloy was used as the dispersed particles and SCM435 steel powder was selected as the matrix. In the fabricated materials, Ti-Ni particles were dispersed uniformly and almost non-deformed in their shape. The relative density was about 95\%. By EPMA and by TEM observations, we confirmed the segregation of $\mathrm{Ti}$ and $\mathrm{Ni}$ at the surface of dispersed particles, and also the diffusion of $\mathrm{Fe}$ into the particles. As the pulse electric current sintering method has advantages of shortening the time for fabrications and lowering the temperature for fabrication, the observed interface segregation layers were more thin in compare with other fabrication method such as HIP. When the crack arrest function is expected, these interface structures are considered to be favorable, because of eliminating the transformation temperature shift in Ti$\mathrm{Ni}$ particles due to local composition change.
\end{abstract}

KEYWORDS

Shape memory alloy, particle dispersed material, pulse electric current sintering, crack arrest function

\section{1 緒言}

近年，形状記憶合金の繊維や粒子を金属あるいは高分子マ トリクス中に分散させ，あるいは埋め込んで，記憶合金の変 態による応力場を亀裂進展の抑止機能に利用しようとする研 究がいくつか報告されている1-3).これは前もってマトリクス 中の分散粒子や埋め込まれた繊維に記憶処理を施して分散材। 埋め込み材中に残留応力場を生じさせる場合と, 使用中の材 料の変形刍裂先端近傍での誘起変態により生じる応力場を利 用しようとする場合とが考えられ，これまでの報告ではマト リクスとしてアルミや銅等の金属とエポキシ等の高分子が用 いられている。しかし，マトリクス材として重要と思われる 鉄基に関しては末だ例がない，我々はこれまで予備焼結及び HIP 法を組み合わせて，龬をマトリクスとしTi-Ni形状記憶合 金粒子を分散させた材料を作製し，粒子の分散率によっては ある程度の莗裂抑止・強化の効果の現れることを見いだして いる4. しかしなかららこの作製法においては, 分散材料の作製 に要する条件が高温・長時間になること，それに伴い分散粒
子ーマトリクス界面に擪い反応層が出来やすくなり変形条件 によっては強化にマイナスとなるような界面割れが生じてし まうこと，また反応層形成に伴って分散形状記憶合金粒子の 組成が大きく変化して粒子の変態温度をずらせてしまうこと 等，多くの問題点が出てきた.これらの問題に対処するため 我々は,パルス通電焼結法を用いて鋼マトリクス中にTi-Ni形 状記憶合金粒子を分散させた材料を作製することを試みた。 まず最初のステップとして，パルス通電焼結法による作製条 件の確立と作製された分散材料の性質(特に界面の性質)の検 討を目的として実験を行った。

\section{2 形状記憶合金分散材料について}

分散させる形状記憶合金を粒子状とした場合，この分散材 料中を進展する亀裂に対し抑止機構として㗢くと考えられる 要因には次のようなものが挙げられる。

(1) 分散粒子周辺への亀裂の回り込みによる応力緩和の効果: これは記憶合金粒子の分散に限らず,ほとんどの分散材料 
の場合に想定される機構であろう.分散粒子の大きさや体 積分率が影響を与えるものと考えられる。

(2) 分散材料の焼結過程において発生する熱応力により,粒子 周囲に生じる圧縮残留応力の効果:マトリクスを鉄基とし た場合，Ti-Ni 合金粒子との熱膨張率の差から冷却過程に おいて粒子周囲に圧縮残留応力が生じると考えられ,これ が亀裂近傍の応力場と相互作用することにより亀裂進展に 対する抑止効果を与える.

(3) 形状記憶合金粒子の記憶効果により生じる圧縮残留応力の 効果: この機構を働かせるためには, 作製した分散材料を 室温で数 \% 程度変形してマルテンサイト相状態の分散粒 子にマルテンサイト晶バリアントの再配列による変形を導 入し, 粒子の Af 点以上の温度 $(373 \mathrm{~K})$ 前後に加熱して形状 記憶合金粒子の母相への変態を起こさせる必要がある.こ の変態により粒子は形状回復のため縮もうとするため, マ トリクス中に圧縮残留応力を生ずる可能性が考えられる. 古屋, 水内らは ${ }^{5,6}$ 形状記憶合金を埋め込んだ複合材にお いてこの機構を提唱している.

(4) 変態温度以上で変形させ亀裂進展させる場合の,応力誘起 変態に伴う粒子の体積変化の効果:これは変形が分散記憶 合金粒子のAf点以上の温度で進行する場合に限られるが， 変形温度において母相状態の粒子が変形応力あるいは進展 亀裂の応力場の影響を受けて誘起変態を起こし,マルテン サイト晶に変わることを想定している.母相からマルテン サイト相への変態は体積変化としては収縮であると言われ ておりつ, マトリクスには引つ張り残留応力を生じて亀裂 抑止にはマイナスであるように考えられるが,亀裂先端近 傍の応力緩和に寄与するという報告もあり なっていない.

いずれにしてもこれらの効果を発現させるためには, 分散 材料として粒子の均一分布，分散材作製過程での粒子の割れ や大きな変形のないこと, 粒子ーマトリクス界面が厚い反応 層の影響などで弱くなりすきないこと等が必要となる. 反応 層に関してはその性質界面の結合の強さによっては亀裂抑止 にプラスする場合もあり得るが(界面剥離による応力緩和等), これは形状記憶合金を利用する場合の本来の狙いとは多少異 なると思われる. (2)(3)の機構に関しては, Eshelbyによる等 価介在物モテルを用いて発生する残留応力の大きさの計算が アルミ基複合材等について試みられている".

\section{3 試料及び実験方法}

上記のような機能を持たせるため, Ti-Ni形状記憶合金粒子 を鋼マトリクス中に分散させた材料を以下の方法で作製した. 用いた粉末は, Ti50-Ni50at.\%の等原子比組成の形状記憶合金 粉末 (粒径 < $40 \mu \mathrm{m}$ : 住友シチックス) 及び SCM 435 組成の鋼粉 末 (粒径 $<70 \mu \mathrm{m}$ : 日立粉末治金) である. Ti-Ni粉末の SEM 写 真を Fig.1 に示す. Ti-Ni粉末の変態温度は DSCにより測定さ れ, Ms =310K, Mf=278K, As =324K, Af=361Kであった．分 散材料の作製にはパルス通電焼結装置(住友石炭製 : SPS-
511S)を用いた. 記憶合金粉末が 1 vol.\%となるように秤量し， 2 種の粉末をボールミルにて混合後, カーボンダイスを用い 種々の加熱温度, 保持時間で焼結を行い, 最適条件を探った。 昇温速度は $100 \mathrm{~K} / \mathrm{min}$ であり, 加圧は $22 \mathrm{MPa}$ の設定とした. 作 製された試料の寸法は直径 $15 \mathrm{~mm}$ ，厚さ $3 \mathrm{~mm}$ である．作製し た分散材料はEPMA及びTEMにより, 粒子ーマトリクス界面 付近の観察を行った.

\section{4 実験結果及び考察}

パルス通電焼結の加熱温度・保持時間と得られた焼結体の 相対密度との関係は, Table 1に示す通りである. なお加熱温 度は, カーボンダイス中に埋め込まれた熱電対の示す温度で ある. 表に示す温度の最低值 $1073 \mathrm{~K}$ は，十分な強度を示す焼 結体を得るための下限値と考えられたので，これ以下の温度 のテータはカットした．表に見られるように一定加圧力 (22MPa)の条件下で加熱温度が高くなるほど, 得られた焼結 体の相対密度は高くなり，ばらつきは小さくなる．加熱温度 が1123K を超えると, 焼結中に試料が一部溶融するのが観察 された. そのため温度を $1093 \mathrm{~K} に$ 抑え保持時間を長めにとる ことにより，ある程度の密度の確保が可能であることが分

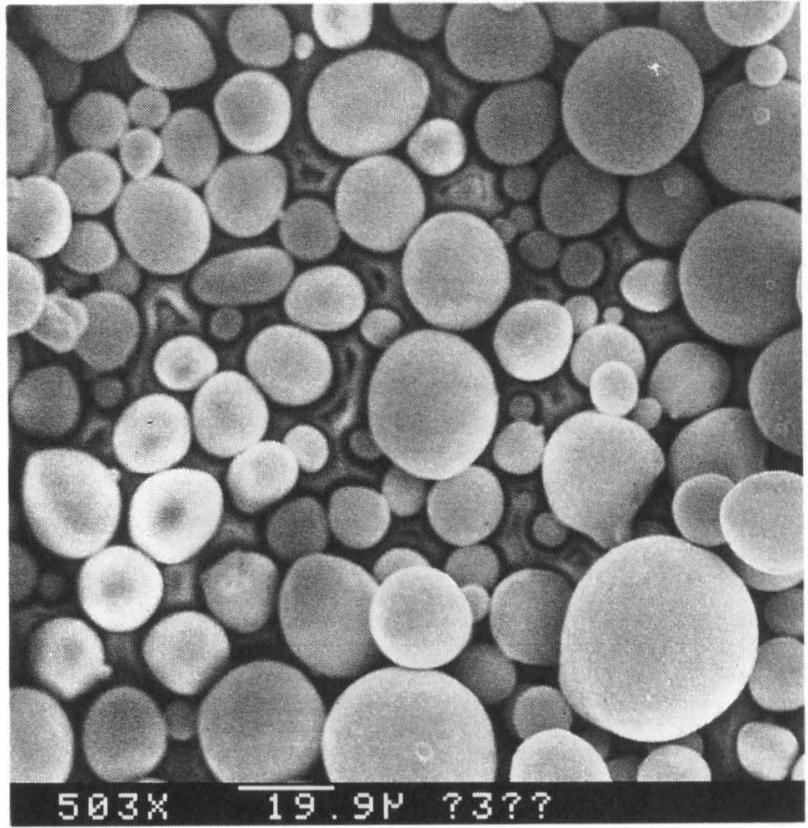

Fig.1 SEM image of Ti-Ni powder.

Table 1 Relative density of sintered materials.

\begin{tabular}{cccc}
$\begin{array}{c}\text { Sintering } \\
\text { Temp.(K) }\end{array}$ & $\begin{array}{c}\text { Heating } \\
\text { time(s) }\end{array}$ & $\begin{array}{c}\text { Holding } \\
\text { time(s) }\end{array}$ & $\begin{array}{c}\text { Relative } \\
\text { density(\%) }\end{array}$ \\
\hline 1073 & $6 \times 10^{2}$ & $6 \times 10^{2}$ & 92.9 \\
1123 & $6 \times 10^{2}$ & $6 \times 10^{2}$ & 93.4 \\
1173 & $6 \times 10^{2}$ & $6 \times 10^{2}$ & 95.5 \\
1093 & $6 \times 10^{2}$ & $1.2 \times 10^{3}$ & 97.0
\end{tabular}


かった.これまで同種の材料を HIP 法により作製した場合に は, $95 \%$ 以上の密度を持ち十分な強度を示す焼結体を得るた めには1373K, 200MPaでの処理が最低温度条件であり, 予備 焼結も含めると $6 \mathrm{~h}$ の時間がかかっていたことを考えると, 少 なくとも時間的には大幅な短縮が確認された. パルス通電焼 結の場合の加熱温度は前述のようにカーボンダイスの温度で あり, 試料自体の温度ではないので試料の温度は Table1 に示 した值より高くなるはずであるが, 現時点では正確な温度は 測定出来ていない. パルス通電烵結法ではその原理から考え て粒子表面が局部的に高温になる可能性があり, 加熱及び保 持時間が短いと試料の温度分布が均一ではないことは考えら れる.

得られた焼結体の光学顕微鏡組織を Fig.2 に示す. Ti-Ni粒 子の変形は全体としては余り見られず,分散も良好であった. マトリクスの組織はパーライトであると考えられ，結晶粒は 細かい. パルス通電焼結後, 保持時間をとらずに電源を切っ て冷却すると,アトマイスにより得られたマトリクス粉末の 焼き入れ組織はそのまま残ることが確かめられているので， 本実験程度の保持時間をとることは実用的な組織を得るため には有効である. 高倍の光学顕微鏡組織からは, $\mathrm{Ti}-\mathrm{Ni}$ 粒子表 面に芯部とは色調の異なった層か観察された。そこで EPMA により $\mathrm{Ti}, \mathrm{Ni}, \mathrm{Fe}$ の各元素の分布を調べた結果を Fig.3に示す. $1173 \mathrm{~K}$ (保持時間 $6 \times 10^{2} \mathrm{~s}$ ) と高温で烤結した場合は, ライン分 析より明らかに粒子表面近傍での Tiの偏析を示し, それに対 しNiは最表面でわずかに偏析が見られるもののTiのピーク位 置ではほとんど検出されておらず, 極端な組成変化の状況が 見て取れる. また粒子表面に食い込む形での Feの偏析層が顕 著に見られる. 焼結温度 $1073 \mathrm{~K}$ (保持時間 $6 \times 10^{2} \mathrm{~s}$ ) の場合には 1173Kの場合ほど極端ではないものの Tiと Ni は粒子表面でそ

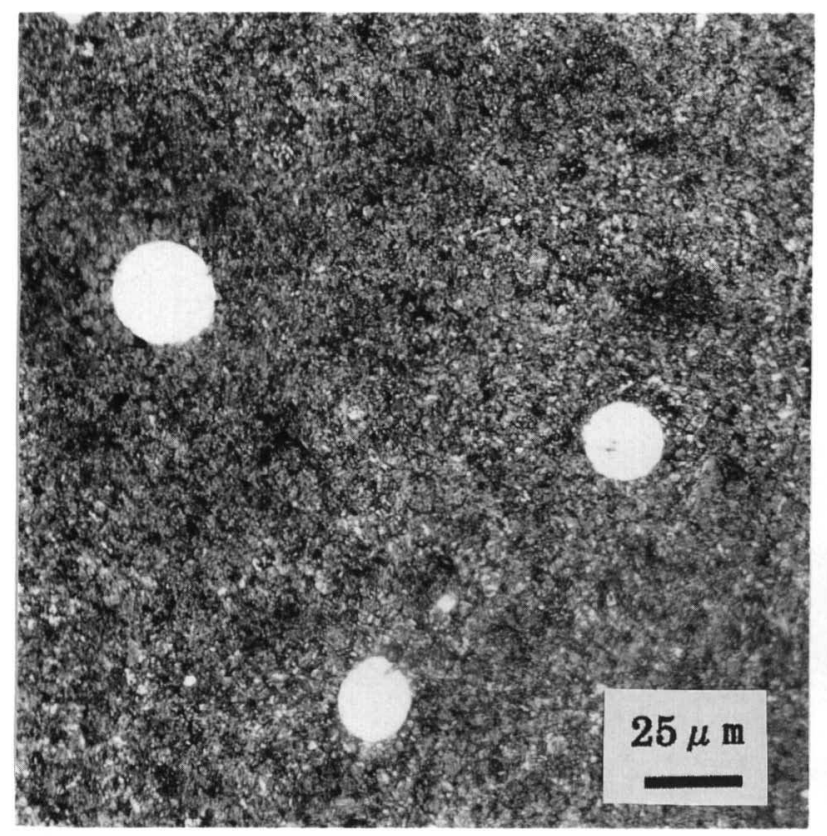

Fig.2 Optical micrograph of sintered specimen. (sintering temperature: $1093 \mathrm{~K}$, holding time: $6 \times 10^{2} \mathrm{~s}$ )
れぞれ偏析を示し，そのピーク位置はずれている. 即ち $\mathrm{Ni}$ の ピークのある位置では Ti 量が隇少(その逆も同様)し, 領域に より異なる偏析状態のあることを示している．このように焼 結に要する時間が短時間であるにもかかわらず粒子表面での 偏析が大きく現れるのは, パルス通電焼結法の特長として粉 末粒子表面に流れる電流のジュール熱による急速加熱が原因 と考えられる. 前述のように焼結温度が高いと鋼マトリクス が一部溶融する場合が観察されたが，これに対応して急速な 拡散による極端な偏析が起こるものであろう. 同じ焼結温度 $1073 \mathrm{~K}$ でも昇温後の保持時間を長めに $\left(1.2 \times 10^{3} \mathrm{~s}\right)$ とつた場合 には, Fig.3(c)のごとく表面偏析がかなり抑えられている. 焼 結が進んで緻密化が進行したあとには, パンチとダイからの 抵抗発熱により全体が均一に加熱されるためではないかと考 えられる.粒子周辺にはやはりTiの飛散が認められた.1073K の焼結では密度のばらつきも多いため, 焼結温度を 1093Kに 上げ保持時間を $1.2 \times 10^{3} \mathrm{~s}$ とった場合最良と思われる焼結体が 得られたので，その粒子表面近傍のEPMA分析を行った結果 が Fig.4である. 粒子表面に Tiの偏析が多少見られるものの, やはり全体として偏析はよく抑えられていることが分かる. このようにパルス通電加熱法により綐結を行っても分散粒子 表面における Ti, Niの偏析は完全にはさけられないが, 焼結温 度と保持時間の組み合わせにより比較的偏析の少ない状態を 得ることが出来る. 本実験では昇温速度を $100 \mathrm{~K} / \mathrm{min}$ に固定し て行ったが,この速度を低めにするあるいはある温度以上か ら昇温速度を低下させるといった条件を与えることで, 短時 間で焼結できることや粒成長を抑えられること等の利点を失 わずにより細かく表面偏析を制御することは可能であろう. 予備焼結と HIP 処理の組み合わせでは, 分散粒子表面の偏析 というよりは粒子ーマトリクス界面に数 $\mu \mathrm{m}$ オーダーの厚い 反応層が観察されており,これを制御して隇少させることは かなり困難であったことから，本実験の目的とする分散材料 を作製するにはパルス通電法を用いるのが有利であると言え る. EPMAにより観察されたTi-Ni粒子表面の偏析層をさらに 詳細に検討するため，TEMによる観察を行った結果を Fig.5 に, また各領域の電子線回折パターンの様子を Fig.6に示す. Fig.5に見られるように,画面上側の鋼マトリクスと接したTi$\mathrm{Ni}$ 粒子 (画面下側) の表面数 $\mu \mathrm{m}$ の領域内に, 針状析出物を含 む層(1), $\mathrm{Ni}$ 偏析層(2)及び $\mathrm{Fe}$ 偏析層(3)が存在する. (1)の針状析 出物は晶癖面を持って出ているように見え, Fig.6(a)の電子回 折像より Ti2Ni と同定され, かなり密に析出していることが 分かる. (2)の層仙 Fig.6(b) から Niリッチの六方晶であること は同定されたが, 正確にあてはまる化合物は見いだせなかっ た. (3) $0.1 \mu \mathrm{m}$ 以下の非常に細かい粒子から成り, MO型の 酸化物であり (Fig.6(c)), EPMAで Feの侵入が見られているこ とから $\mathrm{FeO}$ である可能性が高い. Fig.4において界面付近で少 し○の濃度が上がっていることから，この領域に当たってい るものと思われる. (4)の鋼マトリクスの部分(Fig.6(d)) は, 組 織としてはパーライトであることが確認された. Ti-Ni粒子と 鋼マトリクスとは全体としてよく結合しているが, Ni偏析層 
(a)
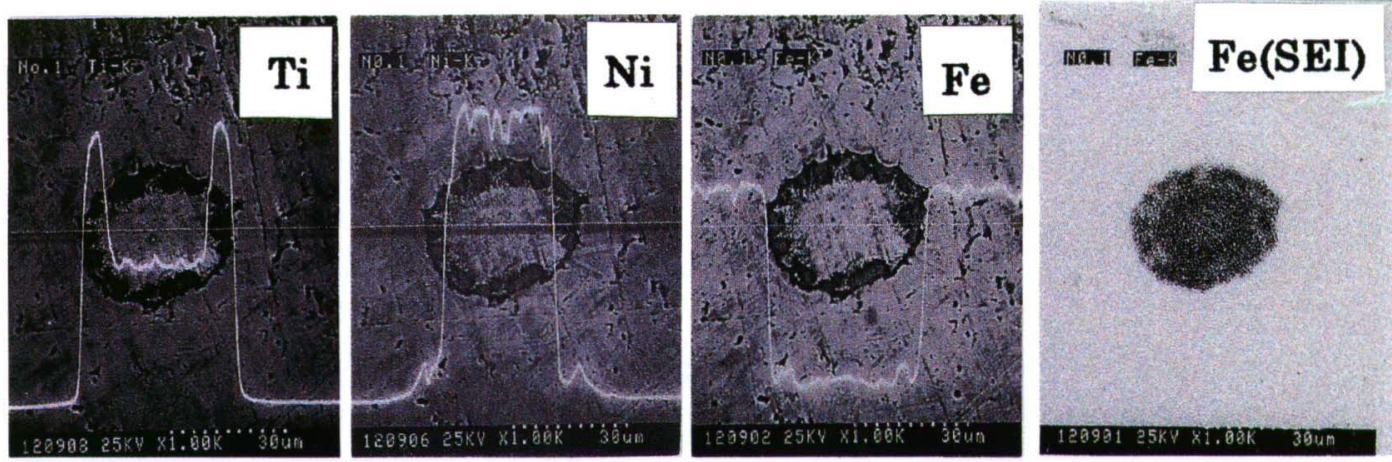

(b)
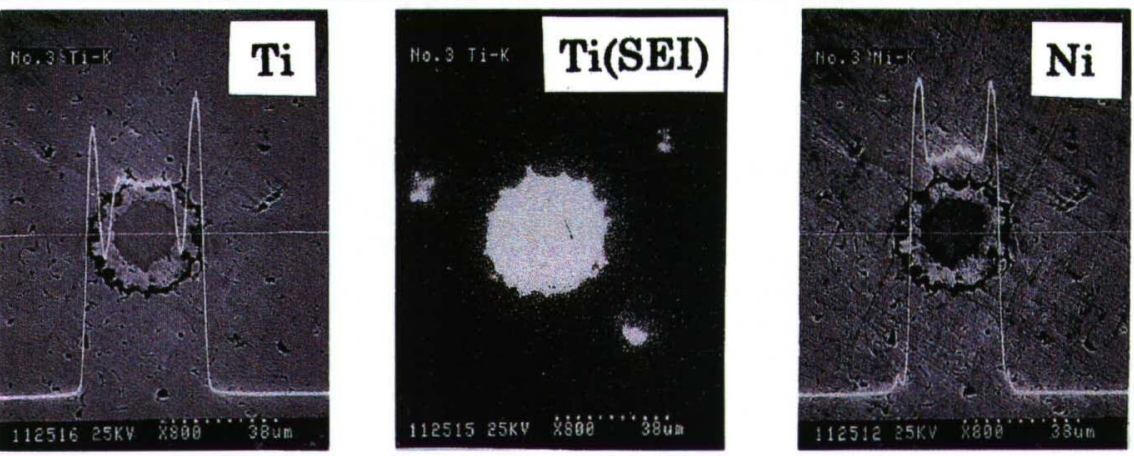

(c)
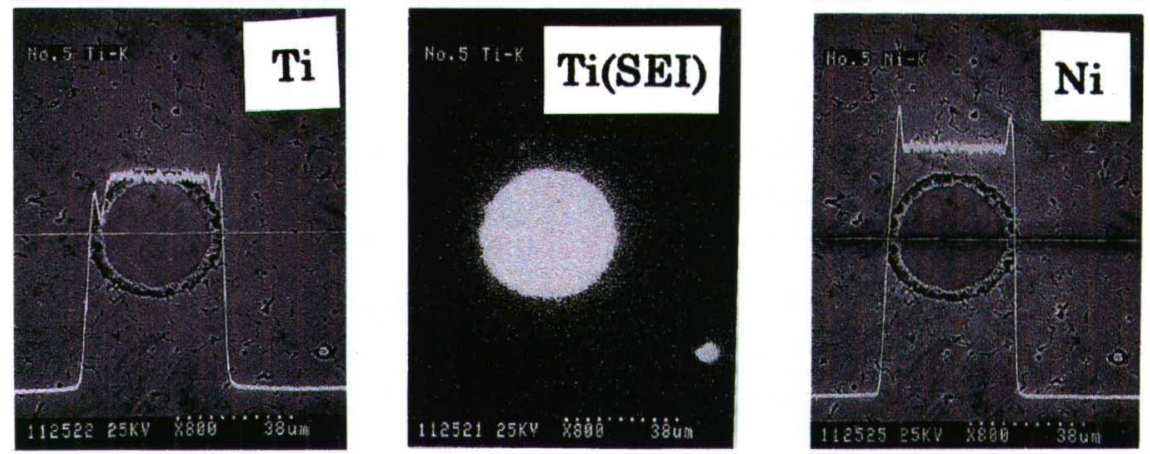

Fig.3 EPMA analysis of dispersed Ti-Ni particles.

(a) sintering temperature: $1173 \mathrm{~K}$ (holding time $6 \times 10^{2} \mathrm{~s}$ )

(b) sintering temperature: $1073 \mathrm{~K}$ (holding time $6 \times 10^{2} \mathrm{~s}$ )

(c) sintering temperature: $1073 \mathrm{~K}$ (holding time $1.2 \times 10^{3} \mathrm{~s}$ )

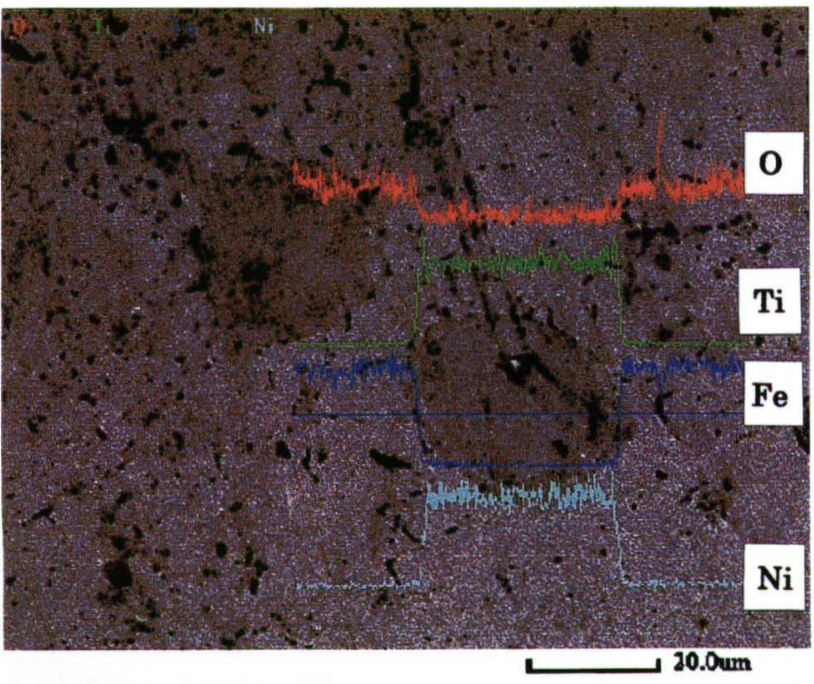

kV: 20 Tik: 0 Mag, $800 x$

Fig.4 EPMA analysis of dispersed Ti-Ni particles. (sintering temperature: $1093 \mathrm{~K}$, holding time: $1.2 \times 10^{3} \mathrm{~s}$ )
とマトリクスの界面では一部剥離が見られる．この剥離は TEM観察のための薄膜試料作製の過程でイオン照射を繰り返 したときに起きているので, この部分の結合が他の部分に比

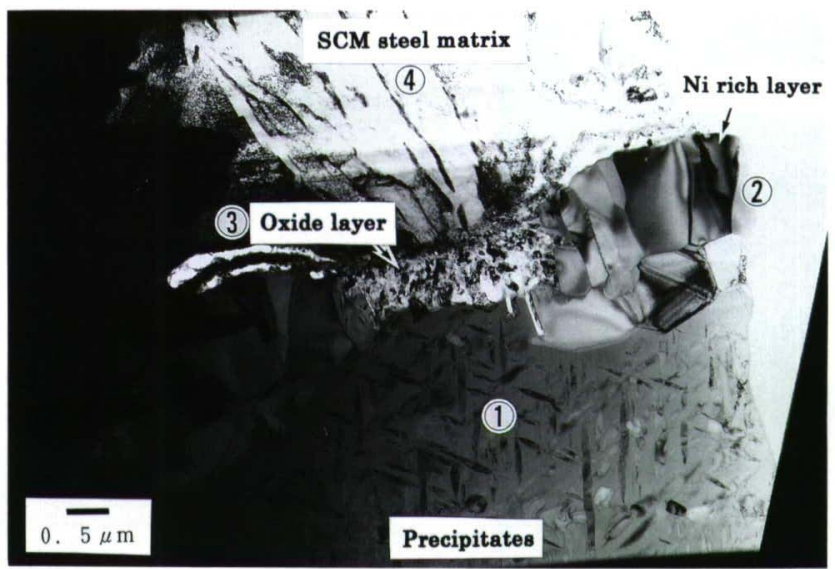

Fig.5 TEM observation of dispersed $\mathrm{Ti}-\mathrm{Ni} /$ matrix interface. 

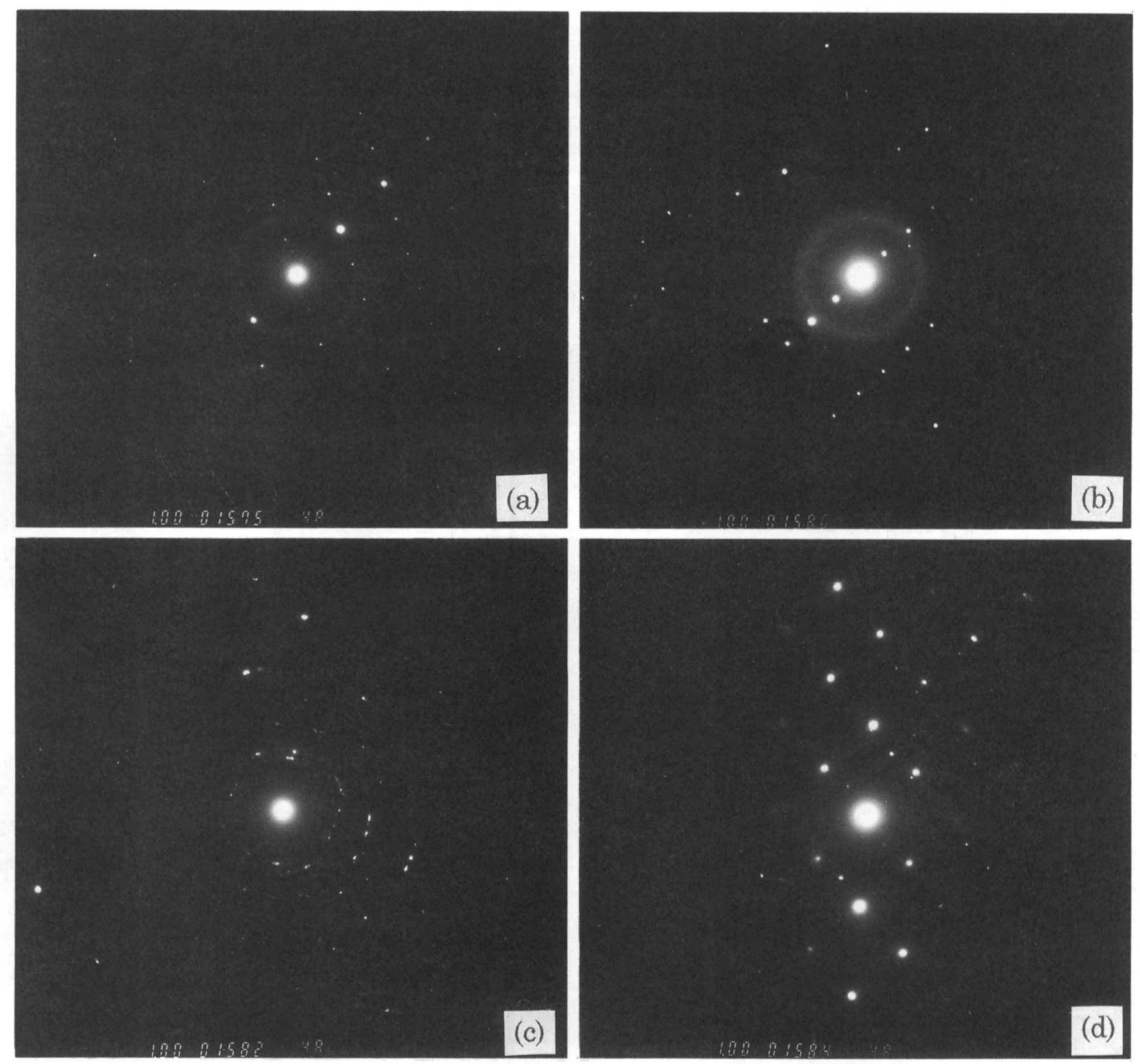

Fig.6 Results of electron diffraction image.

(a) diffraction from needle like precipitates layer (b) diffraction from $\mathrm{Ni}$ rich layer

(c) diffraction from oxide layer (d) diffraction from matrix

ベ弱いことを示している. またマトリクスのパーライト組織 中には転位が多数観察され，これは焼結過程での膨張率差に 起因する熱応力によるものと考えられる.

2において述べたように,形状記憶合金粒子分散による亀裂 抑止機能を発揮させようとした場合に必要と考えられる因子 のうち, 粒子の均一分布, 分散材作製過程における粒子の割 れや変形のないことに関しては，パルス通電焼結による作製 法で満足な結果となっている. HIP 法を用いた場合, しばし ば分散材作製過程で粒子自身にも割れの見られたことから， この結果もパルス通電焼結法の利点であると考えられる.一 方, 粒子ーマトリクス界面での反応層に関しては, HIP 法に より作製された材料に見られたような界面における厚い反応 層及び作製過程における界面の割れ等はパルス通電焼結法に
よる作製においては見られなかったものの，形状記憶合金粒 子表面における成分偏析は存在することが分かった. Ti-Ni形 状記憶合金は Ni濃度が0.1at.\%増大すると Ms, Af 温度が約 $10 \mathrm{~K}$ 下がることが知られており, パルス通電焼結法により分散さ せた Ti-Ni 粒子の Ni 濃度に変化があれば，この分散材を変形 させるときの温度が同じであっても変形機構が変わってくる ことになる. 即ち変形温度を Td として, Td<Mf であれば形 状記憶効果を利用して2(3)の圧縮残留応力の効果を狙うこと が出来るが, Td >Afとなった場合には誘起変態が起きること になり，2(4)の効果を利用する必要がある. HIP 処理により 作製された分散材では前述のようにかなり厚い反応層が形成 され，それに伴っての $\mathrm{Ti}$ 溶出が顕著で, 高温硬さ測定による 変態温度の推定からは Af 点の数 $10 \mathrm{~K}$ の低下が見られた ${ }^{4)}$. パ 
ルス通電焼結法による分散材の作製では Ti-Ni 粒子表面に Ti, Ni の偏析領域があるが，HIP処理による作製に比べ粒子自体 の大きな組成変化は抑えられていると考えられるので，変態 温度の変化が少ないとす机ば，目的とする機能を分散材料に 持たせるためには有用であろう。

\section{5 結言}

パルス通電焼結法を用いて, Ti-Ni形状記憶合金粒子を分散 させた鋼基の分散材料を作製し，以下の結果を得た.

(1) 作製された分散材において，Ti-Ni 形状記憶合金粒子の分 散は良好で,焼結過程での粒子の变形や界面剥離仗見られ なかった．相対密度 95\% 程度の焼結体が HIP 法に比べ短 時間, 低温度で得られ,パルス通電焼結法の利点が確認さ れた。

(2) パルス通電焼結の温度, 保持時間の制御により, 分散粒子 表面近傍での $\mathrm{Ti}, \mathrm{Ni}$ の偏析をある程度抑えられることが分 かった. TEM 観察より，粒子表面の偏析領域ではTiの析 出物相, $\mathrm{Ni}$ リッチの相, $\mathrm{Fe}$ を含む酸化物相の存在が確か められた。

(3) $\mathrm{Ti}, \mathrm{Ni}$ の偏析を抑えることにより，形状記憶合金粒子の変 態温度の变化を少なく报えることが可能であり,これは目的 とする亀裂抑止機能発現のために有用であると考えられた。

\section{文献}

1) 古屋泰文, 田谷稔: "TiNi ファイバ/Al複合材の高温側の強 度と疲労に及ほす形状記憶効果の影響 ", 日本金属学会誌, 60(1996)1163-1172.
2) 中澤忠勝,船見国男,吳林志: "Ti-Ni形状記憶合金粒子を分 散したCu複合材料の機械的性質", 日本機械学会第74期講 演会講演論文集 (I), 東京, (1997)627-628.

3) F.Thiebaud, B.Zeghmati, J.F.Charmoillaux and C.Lexcellent: "Smart Material Thermal Characterization: NiTi Shape Memory Alloy Embedded in a Resin Epoxy Matrix", Proc. of the $3^{\text {th }}$ Intn. Conf. on Intelligent Materials, Ed. by P.F.Gobin and J.Tatibouet, Lyon, INSA de Lyon, SPIE, (1996)535-540.

4) T.Asaoka, K.Kimura and K.Funami: "Characteristics of SMA Particle Dispersed Steel Matrix Composite", J. of Appl. Mech. and Eng., 5(2000) to be published.

5) 古屋泰文, 矢口仁, 斉藤雅弘, 渡邊龍三: " 放電プラスス烧 結による TiNi/Al 基複合材の機械的特性改善", 第6回イン テリジェント材料シンポジウム講演要旨集, 東京, インテ リジェント材料フォーラム,(1997)16-18.

6) 水内潔, 井上漢龍, 田谷稔, 江南和幸, 濱田賢一, 山内清: "TiPd系形状記憶合金ファイバーで強化したTiマトリック ススマートコンボジットの組織と機械的性質", 第8回イン テリジェント材料シンボジウム講演要目集, 東京, インテ リシェント材料フォーラム,(1999)66-67.

7) 舟久保熙康 : 形状記憶合金, 産業図書, (1984)8.

8）古屋泰文,島本聡, 田谷稳: " 形状記憶 $\mathrm{TiNi}$ 纎維強化 $\mathrm{Al}$ 基 複合材での強度向上・疲労亀裂伝播抑制効果 ", 日本機械 学会第 73 期講演会講演論文集, 習志野, (1996)492-493.

9) Y.Yamada, M.Taya and R.Watanabe: "Strengthening of Metal Matrix Composite by Shape Memory Effect", Mater. Trans. of JIM, 34(1993)254-260. 